\title{
Letšeng Diamond Mine, Lesotho: A Variant of Kimberley-type Pyroclastic Kimberlite Emplacement
}

\author{
Casey Hetman ${ }^{1}$, Barbara Scott Smith ${ }^{2}$ Jock Robey ${ }^{3}$, Teboho Nkotsi ${ }^{4}$, Mohapi Mohapi ${ }^{4}$, Thabang \\ Mohapi $^{4}$ \\ ${ }^{1}$ SRK Consulting, Vancouver, BC, Canada, chetman@srk.com \\ ${ }^{2}$ Scott-Smith Petrology Inc., North Vancouver, BC, Canada, barbara@scottsmithpetrology.com \\ ${ }^{3}$ Rockwise Consulting, Kimberley, South Africa,jirobey@telkomsa.net \\ ${ }^{4}$ Letšeng Diamonds (Pty) Ltd., Letšeng-la-terai, Lesotho, Southern Africa,nkotsit@letseng.co.ls \\ ${ }^{4}$ Letšeng Diamonds (Pty) Ltd., Letšeng-la-terai, Lesotho, Southern Africa, mohapim@letseng.co.ls \\ ${ }^{4}$ Letšeng Diamonds (Pty) Ltd., Letšeng-la-terai, Lesotho, Southern Africa, mohapit@letseng.co.Is
}

\section{Introduction}

The Letšeng Diamond Mine comprises two adjacent kimberlites, the Main and Satellite pipes. Very low grade and low frequency of high value stones preclude use of standard evaluation methods, increasing the need for high confidence geology models. New results of drillcore investigations, including core logging, country rock dilution measurements, indicator mineral abundances and petrography are integrated with open pit mapping and macrodiamond production data to present updated 3D geological models of the Main and Satellite pipes (Fig.1).

Letšeng was emplaced $~ 90 \mathrm{Ma}$ and forms part of a Cretaceous kimberlite province extending across southern Africa. The Letšeng bodies are steep-sided volcanic pipes that are infilled with multiple asymmetric phases of kimberlite separated by near-vertical, sharp, cross-cutting internal contacts. There are associated marginal carbonate-cemented country-rock breccias and sub-vertical kimberlite dykes that can occur within a zone of well-developed carbonate veining adjacent to the pipes. The pipe infills are dominated by kimberlite closely resembling Kimberley-type pyroclastic kimberlite (KPK; formerly tuffisitic kimberlite; Scott Smith et al. 2013) that contains common large megaxenoliths of massive and brecciated country rock basalt. Other textural varieties include hypabyssal kimberlite (HK), transitional HK-KPK and resedimented volcaniclastic kimberlite (RVK). Each phase of kimberlite represents a separate magmatic system. In each KPK there is a continuum of crystallization from the magmaclast selvages to the intermagmaclast matrix. As documented elsewhere, the HK-KPK transition involves an increasing (i) degree of deuteric replacement of olivine, (ii) amount of incorporated country rock xenoliths and (iii) textural modification of the magma prior to solidification subsurface within the diatreme. These conclusions negate some other proposed modes of emplacement.

\section{Internal Pipe Geology}

The larger Main pipe (Fig. 1a) was formed by at least five phases of kimberlite emplacement that display decreasing explosivity over time: (i) initial pipe formation now represented by marginal remnants of diverse RVKs deposited into an open crater (RVK-A); (ii) formation of a dominant and relatively uniform KPK-infilled diatreme (K1); (iii) a poorly delineated subsequent RVK-B containing blocks of the latter KPK; (iv) a central nested pipe infilled with inhomogeneous coherent to more pyroclastic kimberlite (K6); and (v) a late cross-cutting irregular intrusive HK pipe-sheet complex (K4). The occurrence of both KPK and RVK is consistent with the estimated erosion of 300-500 m and the southern African composite ‘Hawthorne’ KPK-pipe model.

The Satellite pipe was formed by at least five phases of kimberlite emplacement: (i) an initial pipe infilled with relatively uniform KPK (Southern Volcaniclastic Kimberlite - SVK); (ii) a nested pipe with variable complex KPK-HK textures (Northern Volcaniclastic Kimberlite - NVK); and (iii) three smaller later diverse cross-cutting kimberlites (CVK, CCK and HK dykes). The apparent absence of $\mathrm{RVK}$ in this pipe is consistent with the development of a smaller pipe where the upper crater has been completely eroded. 

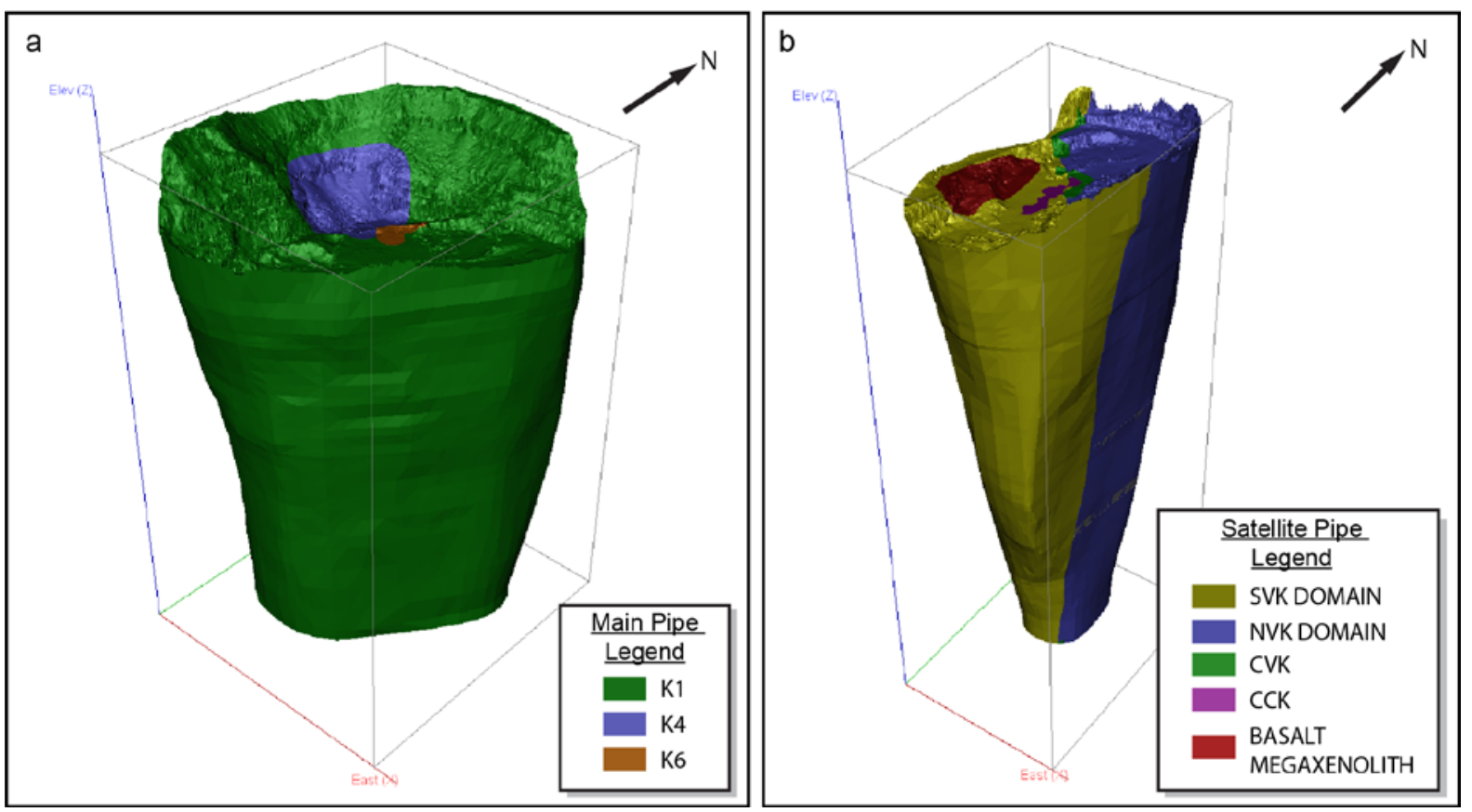

Figure 1: Simplified 3D geological models of the Main (a) and Satellite pipe (b) - looking north west. Note: not all phases of kimberlite are shown.
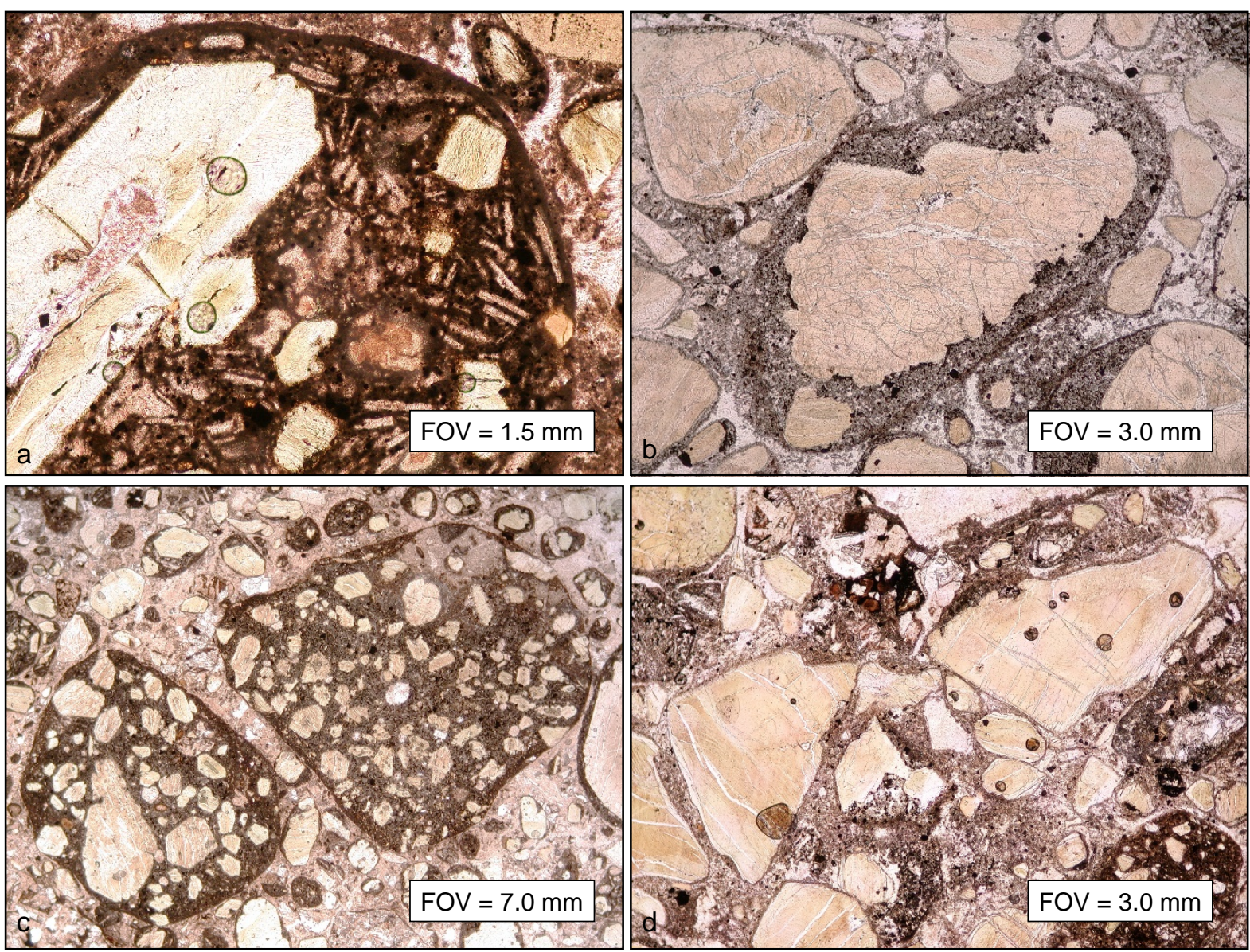
Figure 2: Photomicrographs from the Satellite and Main pipes highlighting some of the key petrographic features from Letšeng KPKs that differ from the type-area KPKs: (a) complex-shaped olivine phenocrysts and common melilite laths within the groundmass of a magmaclast in the SVK, Satellite pipe; (b) the kernel to the central magmaclast is a complex-shaped olivine macrocryst displaying embayed margins interpreted as resulting from resorption in K1, Main pipe; (c) examples of uncored magmaclasts in the SVK with well crystallized groundmass minerals, a feature more typical of Fort à la Corne-type pyroclastic kimberlites (FPK); (d) conspicuous broken olivine macrocrysts from K1 of the Main pipe, another feature more typical of FPK.

\section{Pipe-fill KPK Characterisitics}

Volumetrically, the most significant rock type within the Satellite pipe is SVK and within the Main pipe it is K1; both of these are classified as KPKs. SVK and K1 display macroscopic and petrographic features consistent with type-area KPKs (Fig.2). These include the overall massive structure with only localized layering adjacent to parts of the pipe wall or within the SVK adjacent to megaxenoliths. Both these KPKs contain abundnant locally-derived basalt xenoliths that display limited reaction with the host kimberlite. Olivines are completely pseudomorphed. At Letšeng the KPKs contain atypical olivine phenocrysts that display complex growth features, twinning and may be unusually large $(>1.0 \mathrm{~mm})$. Olivine macrocrysts display extensive embayed margins indicative of resorption. Magmaclasts are abundant with thin groundmass selvages occurring on most olivine crystals and many country rock xenoliths similar to those of typical KPKs (formerly referred to as pelletal lapilli). The magmaclasts at Letšeng also contain abundant uncored examples with well developed groundmass minerals including phlogopite, spinel and perovskite that are atypical of KPKs. Laths of pseudomorphed melilite are widespread, however the size and abundance of these crystals varies. A feature characterisitic of typearea KPKs is the presence of microlites (clinopyroxene / phlogopite / amphibole) surrounding all consituents; although present, the microlites are not as well developed at Letšeng.

\section{Conclusions}

A significant number of features in the Letšeng kimberlites differ from the type-area KPKs including the following: (i) smaller and more complex-shaped olivine macrocrysts; (ii) abundant groundmass melilite and clinopyroxene indicating a more marginal melnoite-like parental magma; (iii) melt-bearing pyroclasts displaying some characteristics similar to Fort à la Corne-type pyroclastic kimberlites; and (iv) widespread common component breakage. The Letšeng kimberlite pipes therefore appear to represent a variant of KPK emplacement that may be characteristic of the Lesotho Highlands and reflect the different craton margin setting and emplacement into $>1500 \mathrm{~m}$ of Karoo basalt that form the Lesotho Highlands. The identification of RVK within the present mining levels of the Main pipe indicate that crater development is much deeper than originally recognized. These features are all important for understanding and predicting the distribution of diamonds at Letšeng.

\section{References}

Scott Smith BH, Nowicki TE, Russell JK, Webb KJ, Mitchell RH, Hetman CM, Harder M, Skinner EMW, Robey JvA (2013) Kimberlite Terminology and Classification. Proceedings of 10th International Kimberlite Conference, Volume Two, Special Issue of the Journal of the Geological Society of India, Volume 2, 1-17. Springer India. 